\title{
Molecular cloning and cDNA characterization of Camelus dromedarius putative cytochrome P450s 1A, 2C, and 3A
}

H.M. Saeed ${ }^{1,2}$, M.S. Alanazi ${ }^{1}$, M.A. Shalaby ${ }^{3}$, O. Alshahrani ${ }^{1}$, F.S. Ataya ${ }^{4}$, A.A. Pathan ${ }^{1}$ and Z.A Abduljaleel ${ }^{1}$

${ }^{1}$ Department of Biochemistry, College of Science, King Saud University, Riyadh, Saudi Arabia

${ }^{2}$ Department of Bioscience and Technology, Institute of Graduate Studies and Research, Alexandria University, Alexandria, Egypt

${ }^{3}$ Genetic Engineering and Biotechnology Research Institute, City for Scientific Research and Technology Applications, Alexandria, Egypt ${ }^{4}$ Department of Molecular Biology, Genetic Engineering Division, National Research Center, Dokki, Cairo, Egypt

Corresponding author: H.M. Saeed

E-mail: hesham25166@hotmail.com / hsaeed1@KSU.EDU.SA

Genet. Mol. Res. 13 (2): 2886-2905 (2014)

Received April 25, 2013

Accepted October 27, 2013

Published March 17, 2014

DOI http://dx.doi.org/10.4238/2014.March.17.1

ABSTRACT. The domesticated one-humped Arabian camel, Camelus dromedarius, is one of the most important animals in the Arabian Peninsula. Most of its life, this animal is exposed to both intrinsic and extrinsic genotoxic factors that are known to cause gross metabolic alterations in many organisms. This study determined the full length coding sequence of 3 cytochrome P450s cDNAs; namely, CYP450 1A1, CYP450 2C and CYP450 3A using reverse transcription polymerase chain reaction. The C. dromedarius CYP450s 1A1, 2C, and 3A have open reading frames of 1563,1473 , and $1566 \mathrm{bp}$ and cDNAs that encode proteins of 520, 490, and 521 amino acid residues, respectively. The molecular weights 
calculated for CYP1A1, 2C, and 3A were found to be 58.651, 56.03, and $58.594 \mathrm{kDa}$, while the predicted calculated isoelectric points using a computer algorithm were 7.315, 6.579, and 9.46. The deduced amino acid sequences of these CYPs showed the membrane anchored signal peptide, the conserved proline-rich amino terminus and the characteristic hemebinding signature localized near the carboxy terminus of the protein.

Key words: Arabian camel; Camelus dromedarius; Cytochrome P450; Xenobiotics; Reverse transcription polymerase chain reaction;

Mixed-functions oxidases

\section{INTRODUCTION}

The Arabian one-humped camel (Camelus dromedarius) belongs to the family Camelidae, which has 6 camel-like animals (1-hump and 2-hump camels, llamas, alpaca, guanaco, and vicuna). This camel is found in the Arabian deserts and arid and semiarid areas of the Middle East (Thomas et al., 1985; Hussein et al., 1992; Al-Khedhairy, 2004). The Arabian camel has unique physiological modifications and is able to live in harsh desert conditions, such as high temperature, direct exposure to sunlight and lack of water resources, with this animal being able to survive without drinking water for weeks (Hussein et al., 1992).

While there has been an increasing number of studies on camels in recent years, pharmacological and biomolecular research of camels remains limited. The Arabian camel genome consists of 74 chromosomes. The DNA sequence of camels exhibits wide variations with other species, including human; however, functional similarities exist. Therefore, studies of camel protein represent a potentially viable target for human applications (Al-Khedhairy, 2004).

Like other living organisms, the Arabian camel is continuously exposed to intrinsic and extrinsic agents that, if not treated properly, may result in mutation and cell death. Many enzymes are involved in the clearance of such compounds such as Phase I and Phase II drug metabolizing enzymes. The clearance of xenobiotics involves both activation (Phase I) and detoxification (Phase II) reactions. Cytochrome P450 monooxygenases (CYPs or P450) are heme-containing proteins belonging to Phase I drug metabolizing enzymes. These enzymes use molecular oxygen and the hydride donor, NADPH, to effect the overall oxidative insertion of one oxygen atom into the substrate (Jung et al., 2011; Nelson, 2011). Cytochrome P450s are involved in the metabolism of a broad range of substrates, and catalyze a variety of chemical reactions, including the conversion of both endogenous and exogenous compounds to more soluble hydrophilic metabolites that are easily removed from the body (Nelson and Strobel, 1987; Nelson et al., 1993). Cytochrome P450s are mixed-functions oxidases that represent one of the body's most important defenses against chemical-induced toxicity. However, in some situations, the metabolism of some chemicals by P450s is undesirable, and may lead to toxic or reactive intermediates, resulting in target organ toxicity and/or carcinogenic insult (Rooney et al., 2004; Nebert and Dalton, 2006; Stiborova et al., 2011).

Most CYP enzymes are expressed constitutively in a variety of mammalian tissues, such as liver, kidney, lung, adrenal gland, and gonads (Seliskar and Rozman, 2007). Many other CYPs are inducible enzymes, and their expression levels increase markedly when exposed to various chemicals, such as ethanol and polychlorinated dibenzo- $\rho$-dioxins (Uppstad et al., 2010). P450 proteins are conveniently arranged into families and subfamilies, based 
on the percentage of amino acid sequence identity. For instance, enzymes that share $\geq 40 \%$ identity are assigned to a particular family designated by an Arabic numeral, whereas those sharing $\geq 55 \%$ identity are assigned to a particular subfamily designated by a letter (Hasler et al., 1999). With the advent of sequencing techniques and the sequencing of genomes of many different organisms, the number of sequenced P450s is rising. At present, the P450 superfamily consists of 12,456 named sequences, with about 6000 more known but not yet named.

The human genome contains 57 genes encoding P450 enzymes and 58 pseudogenes that are distributed in 18 P450 families. Seven of these genes are Type I enzymes, which are found in the mitochondria, while the other 50 genes encode Type II enzymes, which are found in the endoplasmic reticulum (Guengerich, 2004). One-fourth of the human P450s is not well characterized and are termed orphans (Nelson, 2011). The Arabian camel exhibits P450-dependent activities in hepatic and extrahepatic tissues, such as the kidney, lung, spleen, tongue, and the hump (el Sheikh et al., 1991; Raza et al., 1998, 2004; Jung et al., 2011). The present study aimed to isolate and characterize the full-length coding sequence cDNAs of $C$. dromedarius cytochrome P450 1A, 2C and 3A and to assess the degree of similarity of the deduced proteins with those of other ungulates.

\section{MATERIAL AND METHODS}

\section{Chemicals}

All of the chemicals used in this study were of analytical reagent, molecular biology, or chromatographic grade, as appropriate. Water was de-ionized and distilled.

\section{Animals and tissue preparation}

Liver samples from 3 adult male Arabian one-humped camels (C. dromedarius) were obtained from the local slaughterhouse, after the animals were killed under the observation of a skilled veterinarian. The tissue samples selected for RNA preparation and analysis were immediately submerged in RNAlater ${ }^{\mathrm{B}}$ solution (Qiagen, Ambion, Courtabeuf, France) to avoid RNA degradation. The samples were stored at $4^{\circ} \mathrm{C}$ for $24 \mathrm{~h}$, and then stored at $20^{\circ} \mathrm{C}$ until use.

\section{RNA isolation and cDNA synthesis}

Samples of 30-60 mg of the preserved tissues were homogenized in RLT lysis buffer (Qiagen) supplemented with 1\% 2-mercaptoethanol, using a rotor-stator homogenizer (MEDIC TOOLS, Switzerland). Total RNA was extracted using the RNeasy Mini Kit (Qiagen, Germany), with a DNase digestion step, following manufacturer protocols. Elution was performed with $50 \mu \mathrm{L}$ nuclease-free water. Concentration, purity, and quality of the isolated RNA were determined by the Agilent 2100 Bioanalyzer System and Agilent Small RNA analysis kit, following manufacturer protocols (Agilent Technologies, Waldbronn, Germany). Total RNA in aliquots of $2 \mu \mathrm{g}$ was retro-transcribed into single-stranded cDNA by the ImProm-II Reverse Transcription System (A3800, Promega, Madison, USA). Complementary DNA was synthesized by reverse transcription, and used as a template for the amplification of the camel CYPs being studied. 


\section{PCR}

PCR was carried out in a final volume of $50 \mu \mathrm{L}$, containing $25 \mu \mathrm{L} 2 \mathrm{X}$ high-fidelity PCR master mix (GE Healthcare, USA), $5 \mu \mathrm{L}$ c-DNA, $3 \mu \mathrm{L} 30 \mathrm{pM}$ of each primer, CYP1A forward: 5'- GGATCCATGTTCTCTGTGTTTGGACTCTCC-3' and reverse: 5'- GCGGCCGCCTAAG AGCGCATATGCACCT-3'; CYP3A forward: 5'- ATGGACCTGATCCCAAGCTTTTCCTT3' and reverse: 5'-GTCCTTAGGGAAAGTCAGGCTTCATT-3'; and CYP2C forward: 5'- ATGGATCTCTTCATAGTCCTGGTG-3' and reverse: 5'- GACTGGGAATGAAACGGACCTCATAGA-3'. The PCR condition was 1 cycle at $95^{\circ} \mathrm{C}$ for $5 \mathrm{~min}$, followed by 30 cycles at $94^{\circ} \mathrm{C}$ for $1 \mathrm{~min}, 55^{\circ} \mathrm{C}$ for $1 \mathrm{~min}$, and $72^{\circ} \mathrm{C}$ for $2 \mathrm{~min}$. The final extension step was carried out at $72^{\circ} \mathrm{C}$ for $5 \mathrm{~min}$. The PCR products were analyzed on $1 \%$ agarose gel stained with ethidium bromide, at a concentration of $0.5 \mu \mathrm{g} / \mathrm{mL}$.

\section{Cloning and sequencing of the PCR products}

To ligate the PCR products generated onto $\mathrm{pGEM}^{\circledR}$-T Easy vector (Promega Co. Cat No. A1360), $2 \mu \mathrm{L}$ of the product was placed in a clean $0.5-\mathrm{mL}$ tube, to which $1 \mu \mathrm{L}_{\mathrm{pGEM}}{ }^{\circledR}$ T-Easy vector $(50 \mathrm{ng})$ and $1 \mu \mathrm{L} 10 \mathrm{X}$ ligase buffer were added, followed by the addition of $2 \mathrm{U}$ ligase enzyme. The final volume of the ligation reaction was adjusted to $10 \mu \mathrm{L}$, by the addition of nuclease-free water. The tube was incubated at $16^{\circ} \mathrm{C}$ for $16 \mathrm{~h}$. Transformation of Escherichia coli JM109 competent cells was carried out according to Sambrook et al. (1989). The recombinant E. coli JM109 harboring the pGEM $^{\circledR}$-T-Easy vector was screened on selective LB/IPTG/X-gal/Ampicillin/agar plates. Plasmids were prepared from positive clones by the PureYield Plasmid Miniprep System (Cat No. A1222, Promega, Madison, WI, USA).

Sequencing of the PCR products cloned onto pGEM $^{\circledR}$-T-Easy vector (4 different clones) was carried out according to Sanger et al. (1977) by the MegaBACE 1000 DNA Sequencing System (Pharmacia/Amersham Co., USA). The chain termination sequencing reaction was conducted by the DYEnamic ET terminator kit, as an integral part of the MegaBACE 1000 DNA sequencing system. The sequencing reaction products were purified by the DyeEx 2.0 Spin Kit (Qiagen, Cat No. 63206), and applied to the MegaBace 1000 Sequencing machine. The cDNA and amino acid sequences of the camel CYP1A, CYP3A, and CYP2C were aligned with those of other mammals using the ClustalW and DNAStar programs.

\section{Cloning and expression of $C$. dromedarius CYP1A into the pET28a(+) vector}

pGEM $^{\circledR}$-T-Easy plasmid that carries the $C$. dromedarius CYP1A cDNA insert was digested with BamHI and NotI restriction enzymes to release the cloned insert. After agarose gel electrophoresis, the CYP1A fragment was purified from the agarose gel and subcloned into the pET-28a $(+)$ expression vector. The pET-28a $(+)$ (Novagen Co.) plasmid carries an N-terminal His$\mathrm{Tag} /$ thrombin/T7 configuration. The expression of the cloned CYP1A cDNA in pET28a $(+)$ is under the control of the T7 promoter. The pET-28a $(+)$ was digested with BamHI and NotI restriction enzymes, and treated with shrimp alkaline phosphatase (Promega), according to the method of Sambrook et al. (1989). Ligation was carried out in a $10-\mu \mathrm{L}$ final volume that contained $2 \mu \mathrm{L}$ pET$28 \mathrm{a}(+)$ plasmid (20 ng), $2 \mu \mathrm{L}$ CYP1A cDNA insert (20 ng), $1 \mu \mathrm{L} 10 \mathrm{X}$ ligase buffer, and $1 \mu \mathrm{L} 2 \mathrm{U}$ ligase enzyme. The final volume of the ligation reaction was adjusted to $10 \mu \mathrm{L}$ by the addition of 
nuclease-free distilled water. The tube was incubated at $16^{\circ} \mathrm{C}$ overnight. Transformation of E. coli BL21(DE3) pLysS (Promega) competent cells was carried out according to the method of Sambrook et al. (1989). The recombinant E. coli BL21(DE3) pLysS harboring the pET-28a $(+)$ vector was screened on selective LB/IPTG/X-gal/Kanamycin/chloramphenicol/agar plates, and by using the colony PCR strategy utilizing CYP1A gene specific primers. Plasmids were prepared from positive clones using the PureYield Plasmid Miniprep System (Promega, Cat No. A1222).

\section{Expression of recombinant $C$. dromedarius CYP1A in $E$. coli BL21(DE3) pLysS}

A 1-L Erlenmeyer flask containing $200 \mathrm{~mL}$ of terrific broth supplemented with kanamycin and chloramphenicol (Sigma/Aldrich Co., USA) at concentrations of 50 and $35 \mu \mathrm{g} / \mathrm{mL}$, respectively, were inoculated with $2 \mathrm{~mL}$ overnight culture of $E$. coli BL21(DE3) pLysS pET-28a $(+)$ carrying the CYP1A gene. The flasks were shaken at $250 \mathrm{rpm}$ at $37^{\circ} \mathrm{C}$ until the absorbance at $600 \mathrm{~nm}$ was 0.2 , at which point $0.5 \mathrm{mM} \delta$-aminolevulinic acid was added to the culture medium. The incubation was continued until the absorbance at $600 \mathrm{~nm}$ reached 0.8 . Then, $1 \mathrm{mM}$ IPTG was added to the culture and the temperature was adjusted to $30^{\circ} \mathrm{C}$ and $150 \mathrm{rpm}$ for $20 \mathrm{~h}$. After the incubation period, the cells were harvested by centrifugation at $8000 \mathrm{rpm}$ at $4^{\circ} \mathrm{C}$ for $20 \mathrm{~min}$, washed with $50 \mathrm{mM}$ potassium phosphate buffer ( $\mathrm{pH} 7.5$, containing $5.0 \mathrm{mM} \mathrm{MgCl}_{2}$ ), and pelleted for a second time. The cells were then resuspended in $10 \mathrm{~mL} 50 \mathrm{mM}$ potassium phosphate buffer $\left(\mathrm{pH} 7.5\right.$, containing $5.0 \mathrm{mM} \mathrm{MgCl}_{2}$, $0.2 \mathrm{mM}$ DTT, and $10 \%$ glycerol), and sonicated using $4 \mathrm{X} 15 \mathrm{~s}$ pulses. After the first pulse, $1 \mathrm{mM}$ PMSF, $0.1 \mu \mathrm{g} / \mathrm{mL}$ leupeptin, and $0.04 \mathrm{U} / \mathrm{mL}$ aprotinin were added to the tubes and then sonication was continued. Cells debris was removed by centrifugation at $12,000 \mathrm{rpm}$ at $4{ }^{\circ} \mathrm{C}$ for $10 \mathrm{~min}$ after which the supernatant was collected for protein assays and Western blotting.

\section{Total protein determination}

The total protein concentration was assayed by the method of Bradford (1976). A calibration curve was established using bovine serum albumin as a standard at a concentration of $0.5 \mathrm{mg} / \mathrm{mL}$.

\section{Western immunoblotting analysis of recombinant $C$. dromedarius CYP1A}

Recombinant fusion $C$. dromedarius CYP1A protein expressed in E. coli BL21(DE3) pLysS was detected by western blotting using a rabbit polyclonal antibody CYP1A1 (H-70, SC20772, Santa Cruz Biotechnology, INC., USA) raised against amino acids 246-315 mapped onto an internal region of CYP1A1 of human origin. Total proteins were determined, and $50 \mu \mathrm{g}$ was used for the immunoblotting analysis. Proteins were separated by electrophoresis on $12 \%$ SDSpolyacrylamide gel, and transferred to a nitrocellulose membrane (Laemmli, 1970; Towbin et al., 1979). After transfer, the membrane was blocked for $1 \mathrm{~h}$ with $50 \mathrm{~mL} 1 \mathrm{X}$ blocking buffer (SigmaAldrich, USA, Cat. No. B6429). Then, the membrane was first incubated with the primary antiCYP1A1 antibody (1:500 dilution) for $8 \mathrm{~h}$, and then washed for $30 \mathrm{~min}$ with $1 \mathrm{X}$ Tris buffer saline (1X TBS) containing $0.05 \%$ Tween-20. After a final wash with $1 \mathrm{X}$ TBS buffer, the membrane was incubated for $1 \mathrm{~h}$ with anti-rabbit secondary alkaline phosphatase labeled $\operatorname{IgG}$ antibody (1:2000 dilution). The membrane was washed again, and was finally developed using (nitro-blue tetrazolium salt/bromo-chloroindolyl-phosphate substrates. The protein bands were photographed by the Alpha Imager System (Alpha Innotech.Version: 2.0.0.9). 


\section{Structure modeling}

Sequencing data were analyzed using BLASTn, and multiple sequence alignment was carried out using the ClustalW, BioEdit, and DNAStar programs. The CYP protein sequence was obtained by translating the sequenced DNA fragment using the Translation tool at the ExPasy server. The protein sequence was then submitted to the Swiss model server for structure prediction, and the structural data were analyzed by the PDB viewer program. Protein 3D structure models were built based on multiple-threading alignments by LOMET and iterative TASSER assembly simulation (Ortiz et al., 2002; Roy et al., 2010).

\section{RESULTS}

\section{Cytochrome P450 1A, 2C, and 3A cDNA isolation and sequence analysis}

A previous study reported that $C$. dromedarius expresses multiple $\mathrm{P} 450$ isoforms in hepatic and extrahepatic tissues and that most of these enzymes are constitutively expressed. In the previous study, the maximum expression levels of $\mathrm{P} 450$ proteins in the camel liver were in the order of P450 2E1 > $1 \mathrm{~A} 1>3 \mathrm{~A}>2 \mathrm{~B} 1 / 2$. Moreover, detectable levels of the cytochrome P450 side-chain cholesterol cleavage and P450 21-hydroxylase were only observed in the camel testis (Alanazi et al., 2010). In the current study, full length camel P450 1A, P450 2C , and P450 3A were obtained by RT-PCR using gene specific primers designed from the available EST camel genome project data base at http:// camel.kacst.edu.sa/. Utilizing these primers, specific PCR products were obtained that corresponded to 1563, 1473, and 1566 bp for P450 1A, 2C and 3A, respectively (Figure 1). The PCR products were cloned into pGEM-T-Easy vectorand the cDNA inserts were then sequenced. Nucleotide sequences corresponding to 1563,1473 , and 1566 bp were then compared with the nucleotide sequences deposited in the GenBank database using the Blastn program on the NCBI Blast server. The isolated cytochrome P450s showed high statistically significant similarity scores to numerous CYP450s from other species. The full-length cDNAs of $C$. dromedarius CYPs were deposited in the GenBank data base under the accession numbers of JQ619653 for CYP1A, JQ619655 for CYP3A, and JQ619654 for CYP2C. Alignment of the deduced amino acid sequences of $C$. dromedarius CYP $1 \mathrm{~A}, 3 \mathrm{~A}$, and $2 \mathrm{C}$ with other species is shown in Figures 2-4. In the comparison of $C$. dromedarius CYP1A with other ungulates and human, the percentage identity was $83 \%$ for Sus scrofa, $82 \%$ for Bos taurus, $79 \%$ for Macaca mulatta, $78 \%$ for Homo sapiens, and $75 \%$ for Mus musculus (Figures 2-4 and Table 1). Meanwhile, C. dromedarius CYP3A showed $75 \%$ identity with $S$. scrofa, $72 \%$ with $H$. sapiens, and $68 \%$ with M. musculus. Moreover, C. dromedarius CYP2C showed $80 \%$ percentage identity with B. taurus, $74 \%$ with $M$. mulatta, $70 \%$ with $S$. scrofa and $68 \%$ with $H$. sapiens. The open reading frames of $C$. dromedarius CYP1A, 3A and 2C contained coding regions of 1563, 1566 and 1473 nucleotides, and the deduced amino acid sequences represented 520, 521 and 490 amino acids residues with predicted calculated molecular weights of 58.651, 58.594 and 56.030 $\mathrm{kDa}$, respectively (Figures 5-7). Based on the amino acids composition, the predicted calculated isoelectric points using a computer algorithm were found to be 7.315 for CYP1A, 9.46 for CYP3A and 6.579 for CYP2C. 


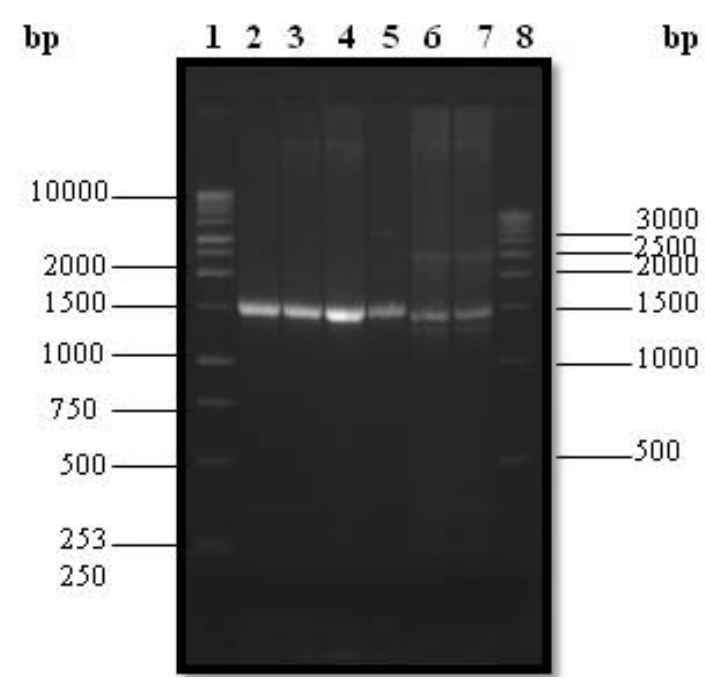

Figure 1. Agarose gel (1.0\%) electrophoresis of PCR products for Camelus dromedarius CYP1A (lanes 2 and 3), CYP3A (lanes 4 and 5) and CYP 2C (lanes 6 and 7) cDNA. lanes 1 and 8 represent 1- and 0.5-kbp DNA molecular weight markers.

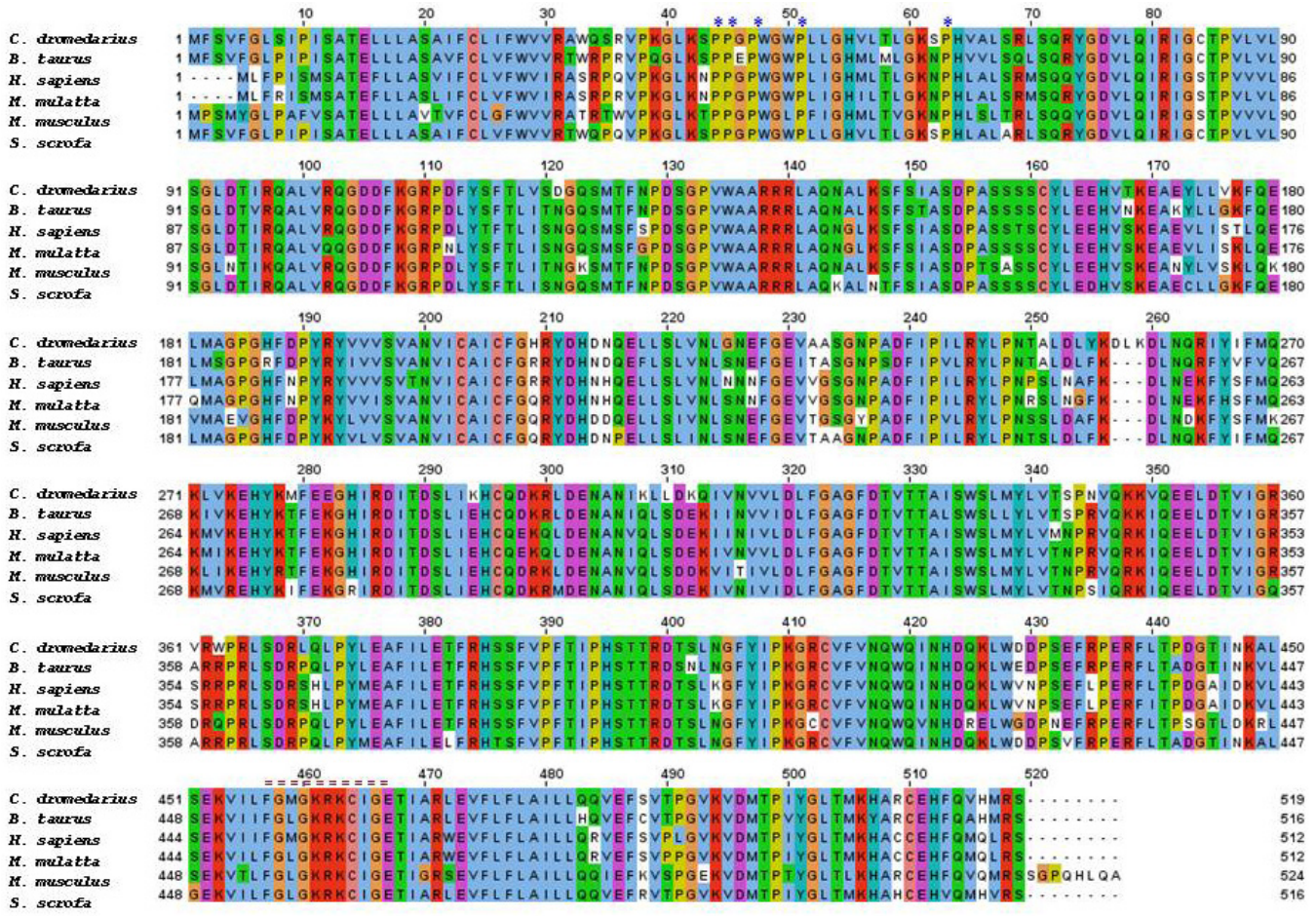

Figure 2. Alignment of the deduced amino acid sequences of Camelus dromedarius CYP1A (accession No. JQ619653), Bos taurus (accession No. DAA17555), Homo sapiens (accession No. P04798), Macaca mulatta (accession No. Q6GUR1), Mus musculus (accession No. P00184), and Sus scrofa (accession No. BAB85660). 


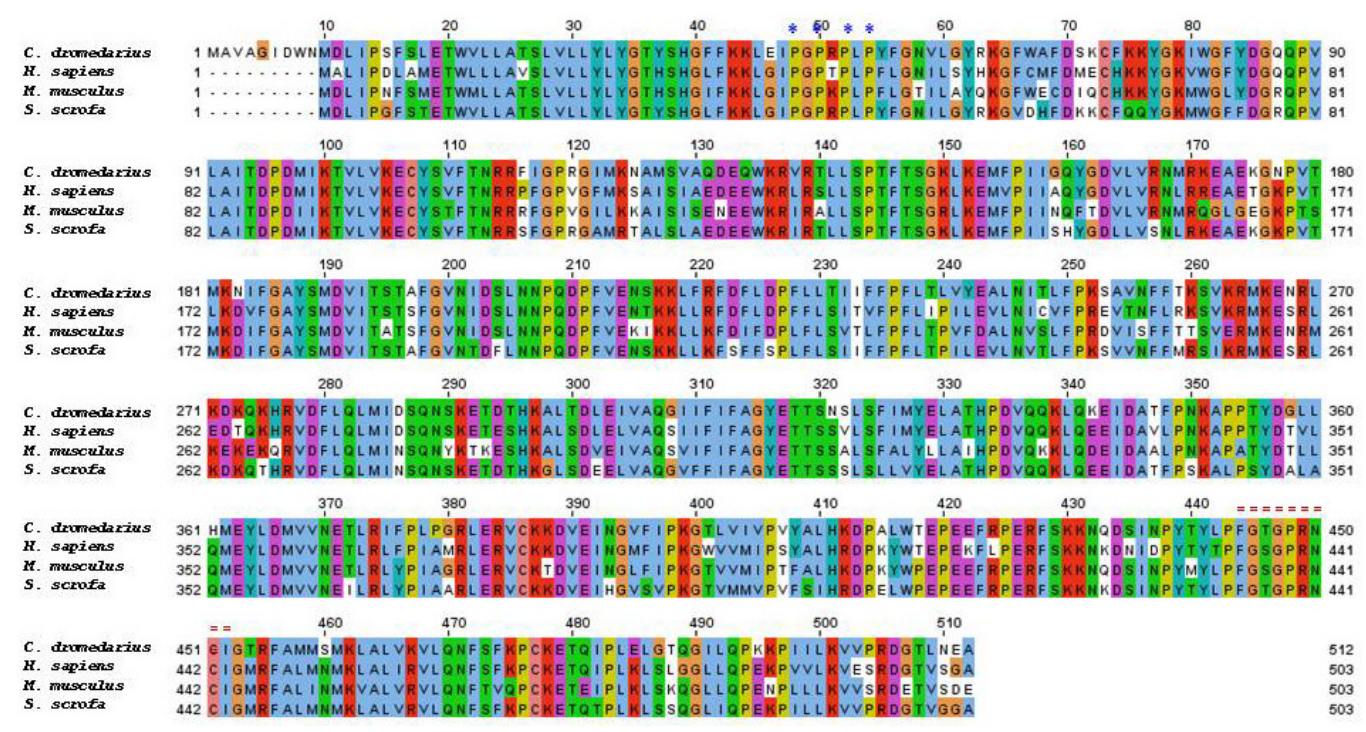

Figure 3. Alignment of the deduced amino acid sequences of Camelus dromedarius CYP3A (accession No. JQ619654), Homo sapiens (accession No. AAA35744), Mus musculus (accession No. Q64464), and Sus scrofa (accession No. AAD04628).

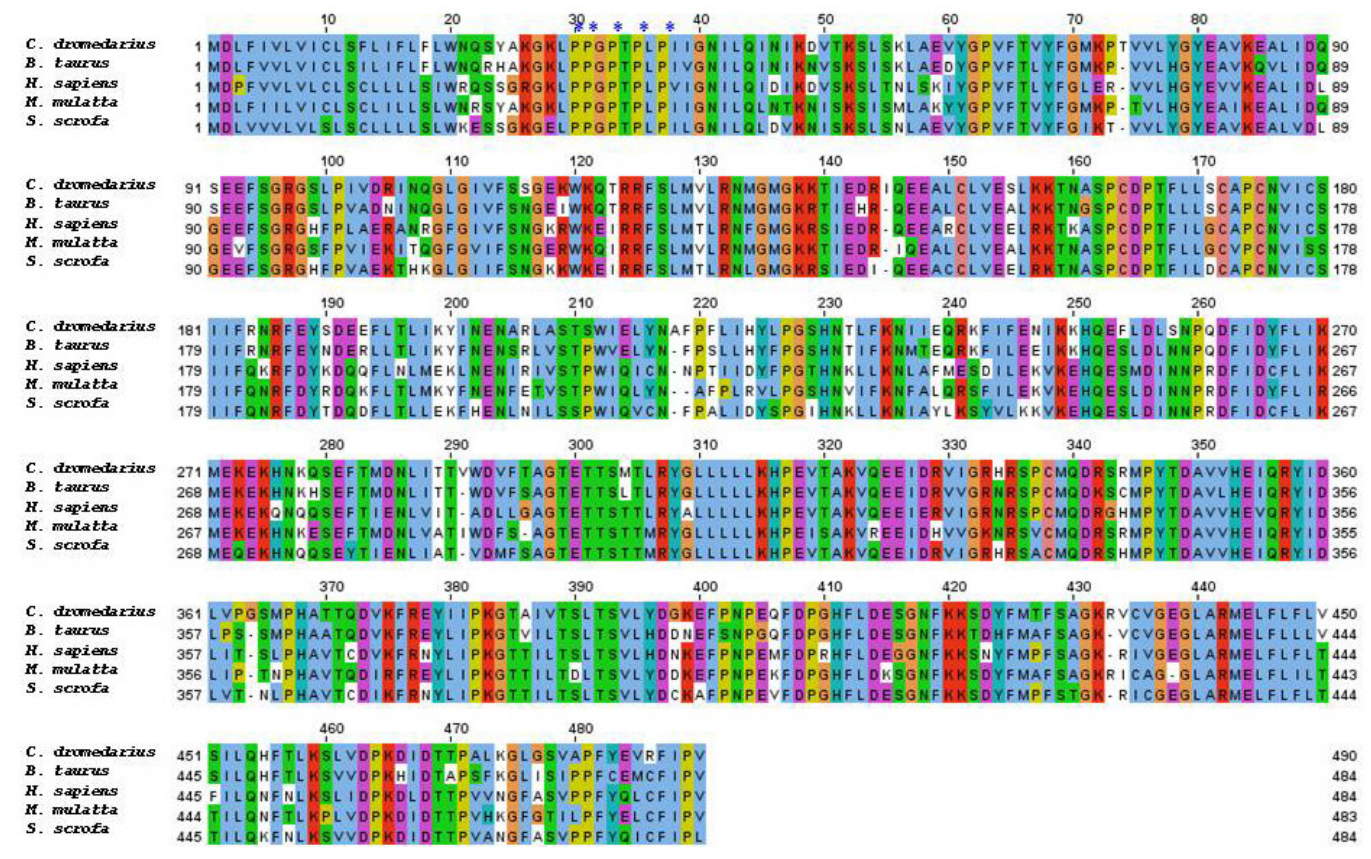

Figure 4. Alignment of the deduced amino acid sequences of Camelus dromedarius CYP2C (accession No. JQ619655), Bos taurus (accession No. AAI53846), Homo sapiens (accession No. AAB59426), Macaca mulatta (accession No. ABB87189) and Sus scrofa (accession No. XP_001924722). Asterisks show the proline-rich regions and red-dashed lines show the conserved heme-binding sites. 
Table 1. Homology of Camelus dromedarius CYPs with other species.

\begin{tabular}{|c|c|c|c|c|c|c|}
\hline \multirow[t]{2}{*}{ Animal species } & \multicolumn{2}{|c|}{ CYP1A } & \multicolumn{2}{|c|}{ CYP3A } & \multicolumn{2}{|c|}{ CYP2C } \\
\hline & Accession No. & Identity (\%) & Accession No. & Identity (\%) & Accession No. & Identity (\%) \\
\hline Sus scrofa & BAB85660 & 83 & AAD04628 & 75 & NP_001161307 & 70 \\
\hline Ovis aries & P56591 & 83 & AAB02657 & 74 & ADZ11091 & 79 \\
\hline Bos taurus & DAA 17555 & 82 & DAA15042 & 74 & AAI53846 & 80 \\
\hline Equus caballus & XP_001493959 & 82 & ABS52842 & 75 & XP_001502043 & 78 \\
\hline Felis catus & Q5K̄QT7 & 81 & BAK52240 & 73 & XP_003994279 & 74 \\
\hline Otolemur garnettii & XP_003784563 & 81 & XP_003798916 & 72 & XP_003787365 & 71 \\
\hline Macaca mulatta & Q6̄̄UR1 & 79 & AAT 49270 & 71 & $\mathrm{ABB} 87189$ & 74 \\
\hline Homo sapiens & P04798 & 78 & AAA35744 & 72 & AAB59426 & 68 \\
\hline Mus musculus & P00184 & 78 & Q64464 & 72 & BAA04555 & 65 \\
\hline
\end{tabular}

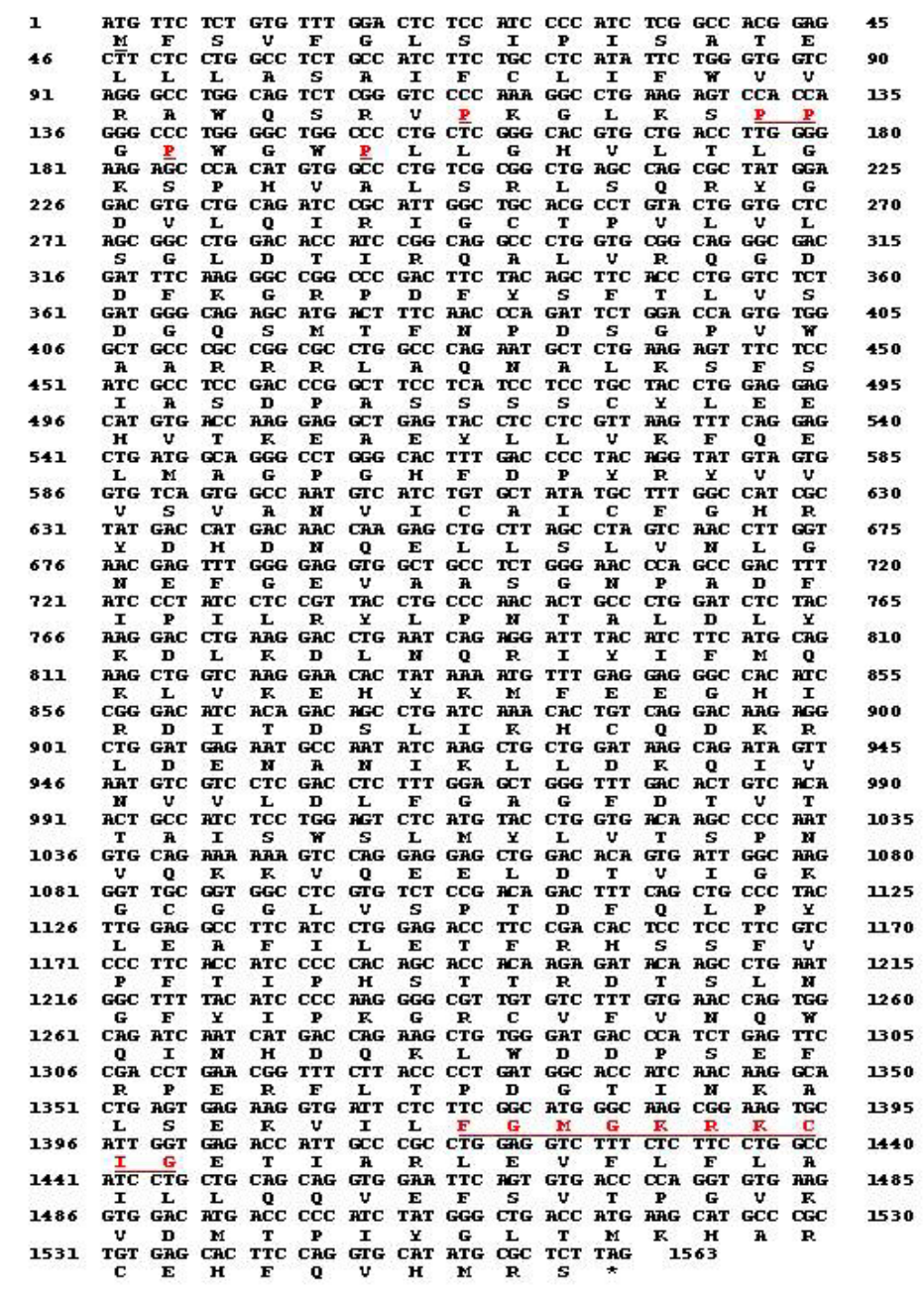

Figure 5. Nucleotides and deduced amino acid sequences of Camelus dromedarius CYP1A. Proline-rich regions and heme-binding sites are underlined in red. 
1 ATG GCG GTC GCG GGA ATC GAT TGG AHC ATG GAC CTG ATC CCA AGC

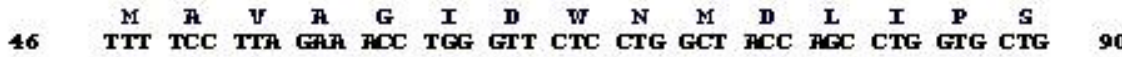

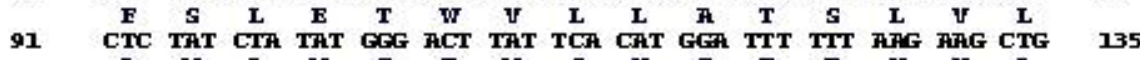

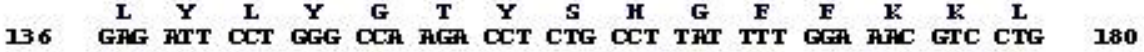

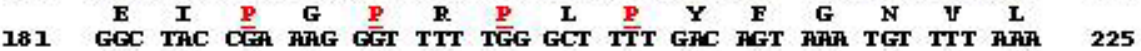

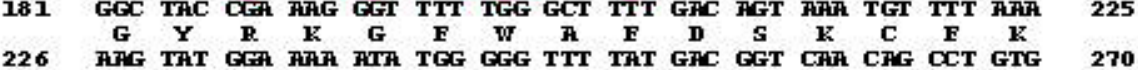

226 AHG THT GGA HAH FIA TGG GGG TTT TAT GAC GGT CHA CFG CCT GTG 270

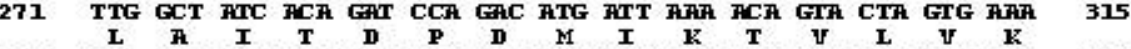

316 GPA TGT TAT TCT GTC TTC ACA AFT CGG AGG TTC ATT GGC CCA AGG 360

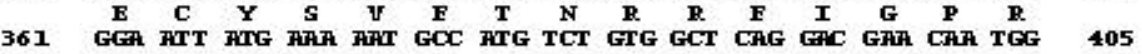

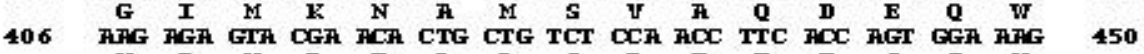

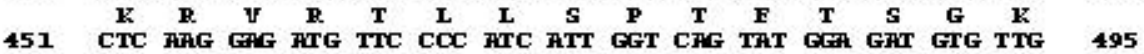

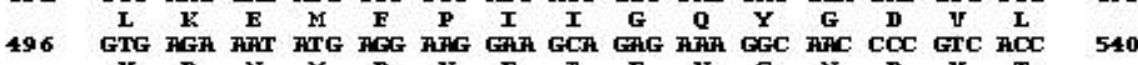

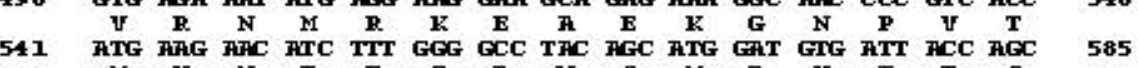

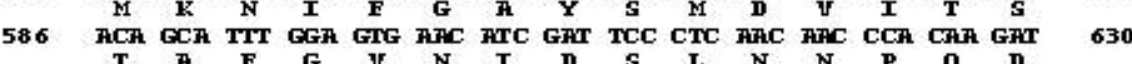
$\begin{array}{lllllllllllllll}\mathbf{T} & \mathbf{A} & \mathbf{F} & \mathbf{G} & \boldsymbol{V} & \mathbf{N} & \mathbf{I} & \mathbf{D} & \mathbf{S} & \mathbf{L} & \mathbf{N} & \mathbf{N} & \mathbf{P} & \mathbf{Q} & \mathbf{D}\end{array}$

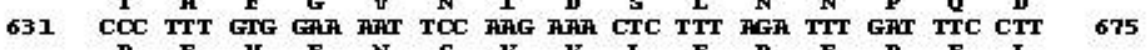

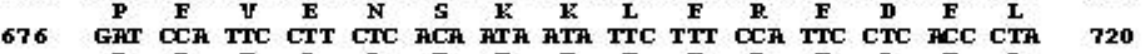

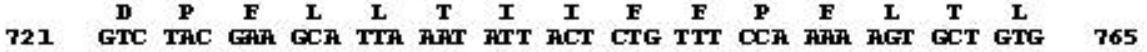

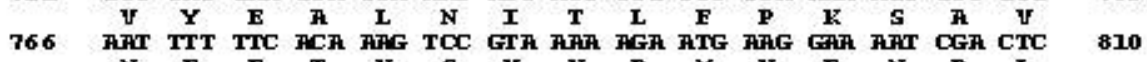

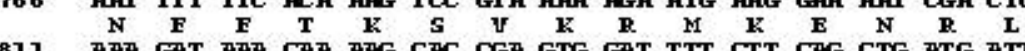
AHA GAT AHA CAH AIA CAC CGA GTG GAT TTT CTT CAG CTG ATG ATT 855

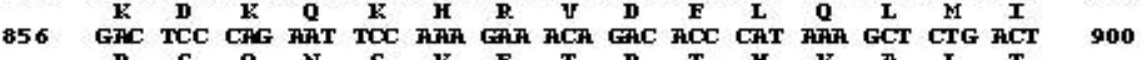
$\begin{array}{lllllllllllllll}\mathbf{D} & \boldsymbol{S} & \mathbf{Q} & \mathrm{N} & \boldsymbol{G} & \mathbf{K} & \mathbf{E} & \mathbf{T} & \mathbf{D} & \mathbf{T} & \mathbf{H} & \boldsymbol{K} & \boldsymbol{A} & \mathbf{L} & \mathbf{T}\end{array}$

901 GFC CTh GAF FTA GTG GCC CAh GGC FTT ATC TTT FTT TTT GCT GGC

946 TAT GAG FCC ACC FGC AFT TCT CTC TCC TTC ATT FTG TAT GAH CTG $\begin{array}{lllllllllllllll}\mathbf{Y} & \mathbf{E} & \mathbf{T} & \mathbf{T} & \mathbf{S} & \mathbf{N} & \mathbf{S} & \mathbf{L} & \mathbf{S} & \mathbf{E} & \mathbf{I} & \mathbf{M} & \mathbf{Y} & \mathbf{E} & \mathbf{L}\end{array}$ GOC ACG CAC DCC GAT GTC CAG CAG FARG CTA CAG AFG GFG ATC GAT

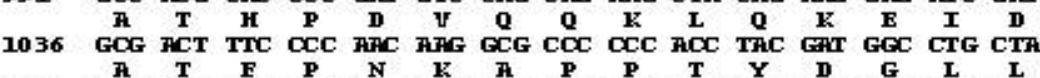

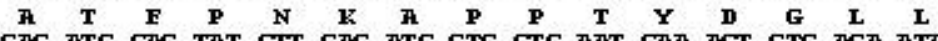

1081 CAC ATG GAG TAT CTT GAC ATG GTG GTG AFT GHA ACT CTC FGA ATA $\begin{array}{lllllllllllllll}\mathbf{H} & \mathbf{M} & \mathbf{E} & \mathbf{Y} & \mathbf{L} & \mathbf{D} & \mathbf{M} & \boldsymbol{V} & \boldsymbol{V} & \mathbf{N} & \mathbf{E} & \mathbf{T} & \mathbf{L} & \mathbf{R} & \mathbf{I}\end{array}$

1226 TTC CCA CTT CCT GGG AGA CTG GHG AGG GTC TGT AFG AHA GAT GTE

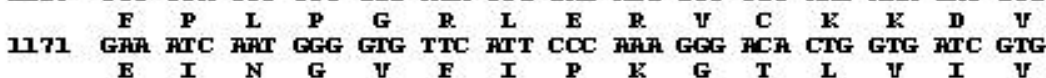

1216 CCA GTC TAC GCT CTT CAC HAH GAC CCA GCA CTT TGG ACA GAG CCT $\begin{array}{lllllllllllllll}\mathbf{P} & \boldsymbol{V} & \mathbf{Y} & \mathbf{A} & \mathbf{L} & \mathbf{H} & \mathbf{X} & \mathbf{D} & \mathbf{P} & \mathbf{A} & \mathbf{L} & \mathbf{W} & \mathbf{T} & \mathbf{E} & \mathbf{P}\end{array}$

1261 GAG GAG TTC CGT COG GPA FGG TTC AGC AAG AIAG AHC CAG GAC AGC

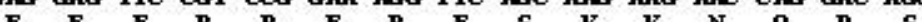

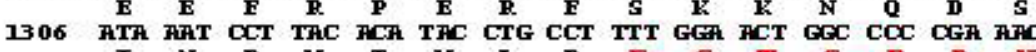

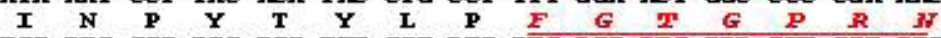

1351 TEC ATC GGC ACG AGG TTT GCT ATG AT̈G AGC FTG FHम CTT GCT CTC

1396 GTC $I$ H

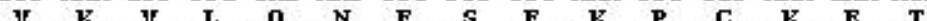

1441 CAG ATC CCC CTG GAT TTA GGC ACT CAH GGC ATT TTG CAH CCG AIA

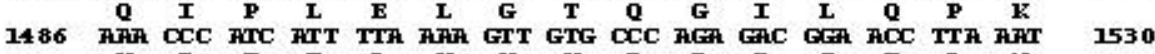

1531 $\begin{array}{lllllllllllllll}\mathbf{R} & \mathbf{P} & \mathbf{I} & \mathbf{I} & \mathbf{L} & \boldsymbol{K} & \boldsymbol{V} & \boldsymbol{V} & \mathbf{P} & \mathbf{R} & \mathbf{D} & \mathbf{G} & \mathbf{T} & \mathbf{L} & \mathbf{N}\end{array}$ 


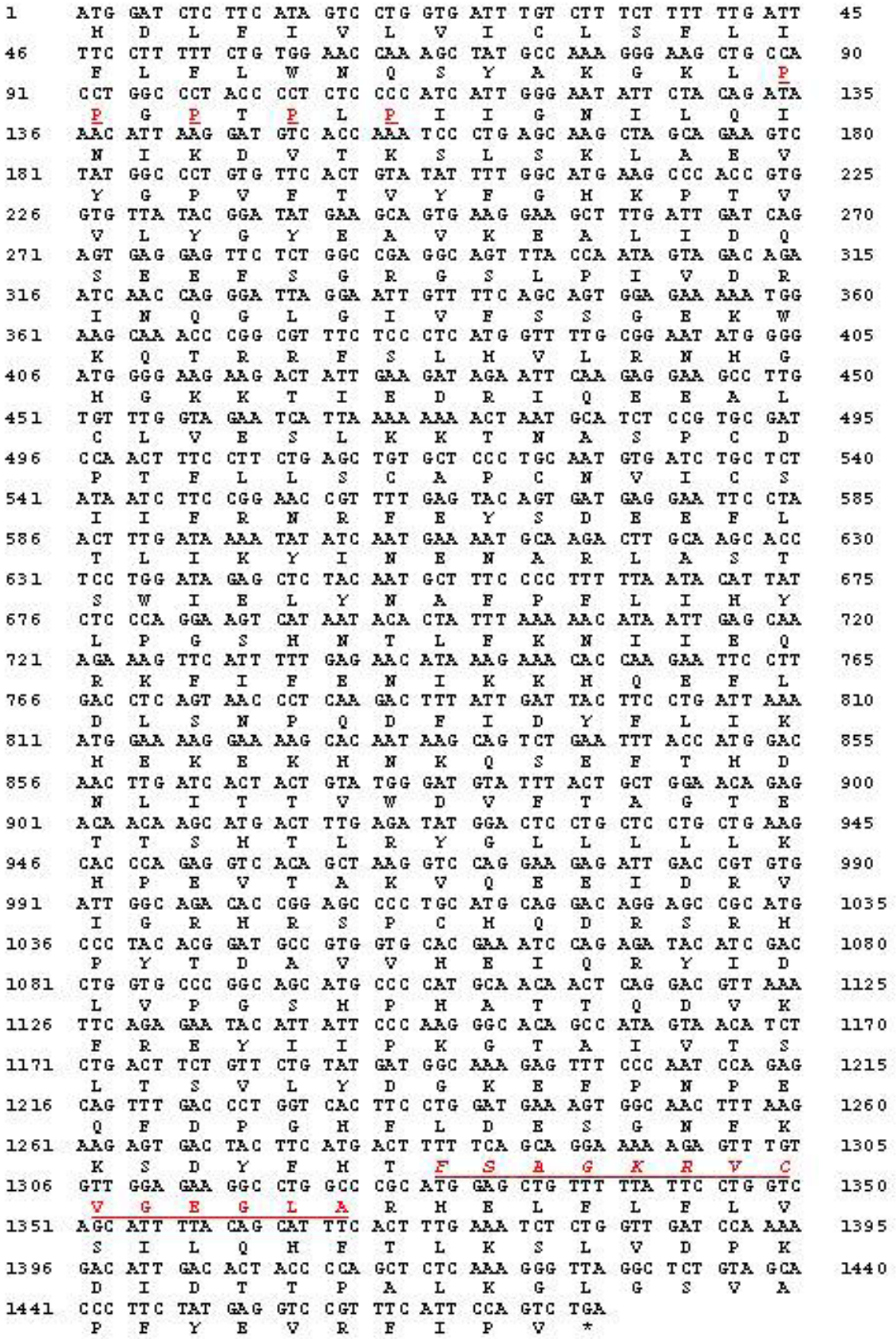

Figure 7. Nucleotides and deduced amino acid sequences of Camelus dromedarius CYP2C. Proline-rich regions and heme-binding sites are underlined in red. 


\section{Predicted 3D structure of $C$. dromedarius CYP1A, 3A and 2C}

The Arabian camel CYP1A, 3A and 2C proteins motifs secondary structures annotation prediction showed several common characteristic features for CYPs (Figures 8-10). First, the N-terminal hydrophobic segment or signal anchor segment (amino acid residues 1-38). Second, following the N-terminal signal peptide there is a proline-rich region (4-5 proline residues). Third, there is a highly conserved heme-binding cysteine-containing peptide that is localized near the C-terminal end of the CYP proteins that forms a pocket in the 3D structure of the CYPs. This cysteine-containing pocket contains up to 10 amino acid residues (Figure 11 ), including the invariant cysteine residue that is involved in the ligation of the heme iron prosthetic group. Figure 5 shows the alignment of $C$. dromedarius $\mathrm{CYP} 1 \mathrm{~A}, 3 \mathrm{~A}$ and $2 \mathrm{C}$ sequences with the CYP sequences of other species around the heme-binding site. Comparing the 3 camels CYP heme-binding signatures revealed the conservation of the invariant amino acid residues (phenylalanine, glycine, and cysteine) in the 3 isolated CYPs cDNA (Figure 11). Proteins with similar amino acid sequences have a tendency to adopt similar 3D structures. Camel 3D CYP1A, 3A, and 2C protein crystal structural models were predicted from amino acid sequences using the I-TASSER server based on multiple-threading alignments by LOMETS and iterative TASSER assembly simulations to obtain the most precise 3D structural prediction. Figure 12 show the overall fold and secondary structure contents of the camel CYP $1 \mathrm{~A}, 3 \mathrm{~A}$ and $2 \mathrm{C}$ as ribbon diagrams. The 3 camel CYPs structures clearly contain the same set of secondary structures elements in very similar folds, with respect to the positions of alpha helices, $\beta$-strands, and the highly conserved $\beta$-bulge or cysteine-pocket. The heme moiety of the CYPs is covalently bound to the invariant cysteine $\left(\mathrm{Cys}^{465}\right.$ for CYP1A, Cys ${ }^{451}$ for CYP3A, and $\mathrm{Cys}^{435}$ for CYP2C), which is found in the $\beta$-bulge region called the cysteine pocket.

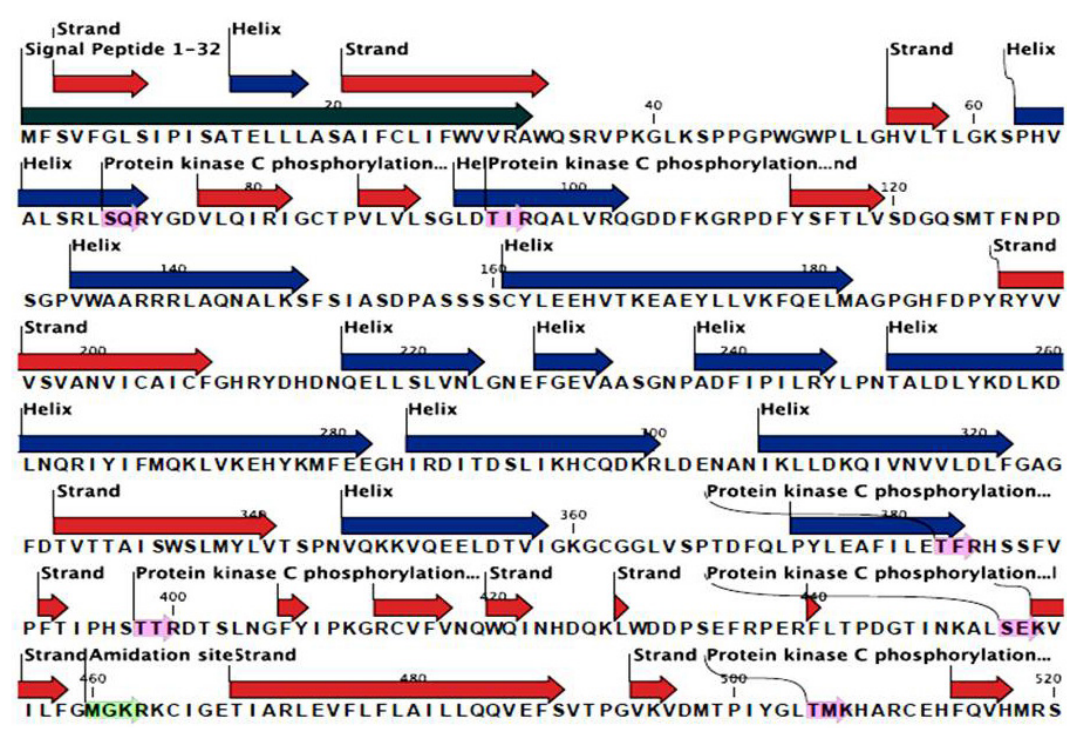

Figure 8. Arabian camel CYP1A protein motifs secondary structure annotation prediction showing the N-terminal signal peptide, proline-rich region, heme-binding site and protein kinase C-phosphorylation sites, along with secondary structure prediction. 


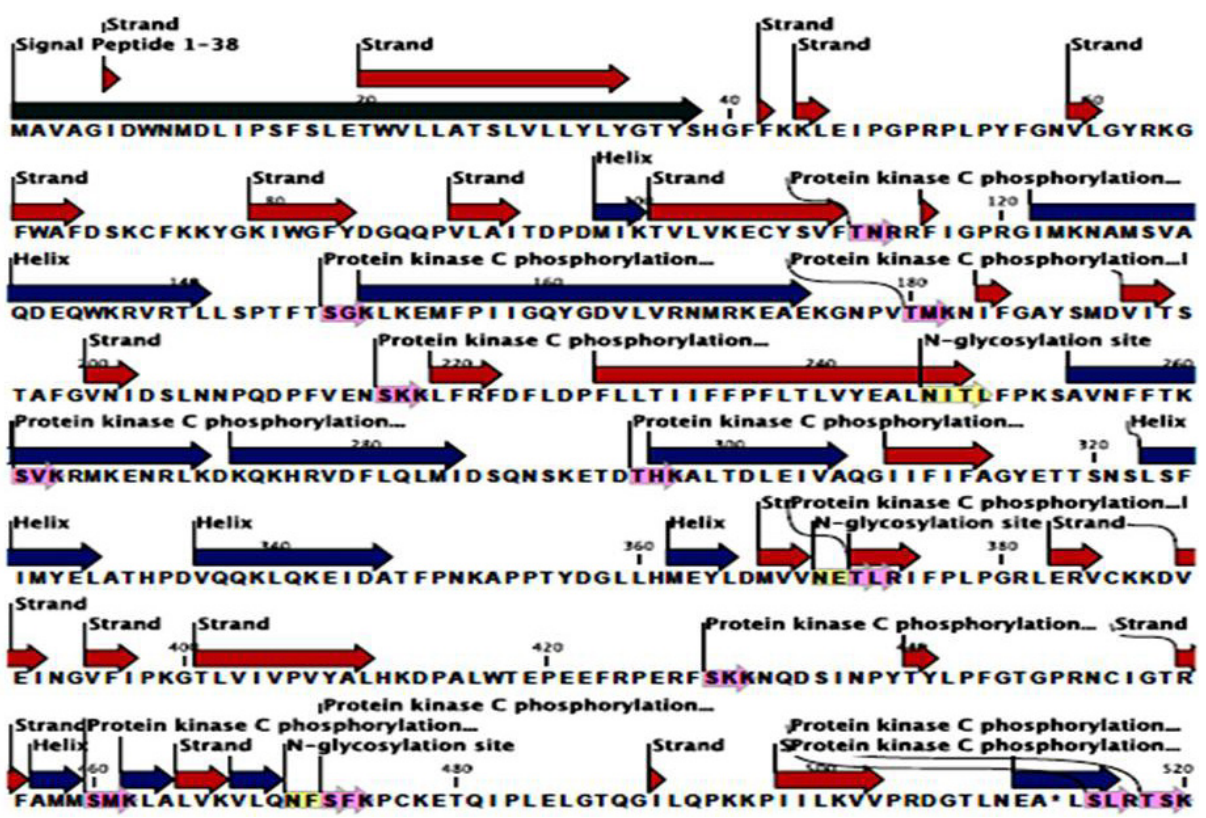

Figure 9. Arabian camel CYP3A protein motifs secondary structure annotation prediction showing the N-terminal signal peptide, proline-rich region, heme-binding site and protein kinase C-phosphorylation sites along with secondary structure prediction.

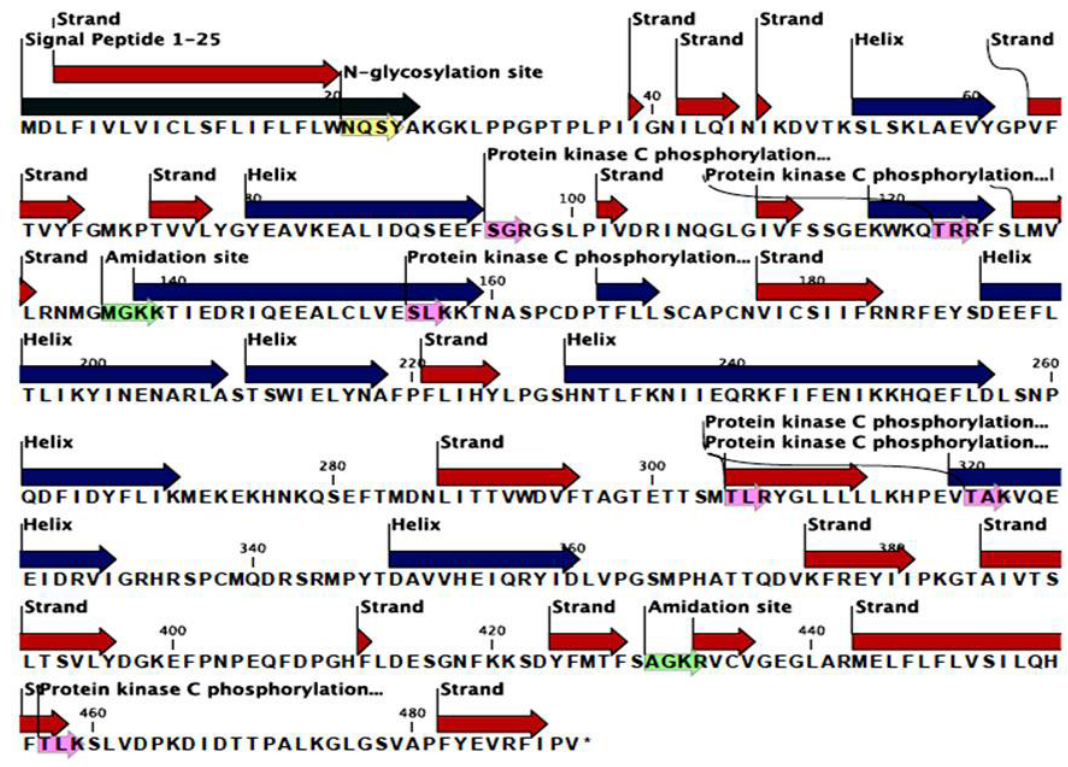

Figure 10. Arabian camel CYP2C protein motifs secondary structure annotation prediction showing the N-terminal signal peptide, proline-rich region, heme-binding site and protein kinase C-phosphorylation sites along with secondary structure prediction. 


\begin{tabular}{|c|c|c|}
\hline \multirow{14}{*}{ CYP1A } & K YLF GL GKRK CIGETIAR & Macaca mulatta (Rhesus monkey) (EHH27476) \\
\hline & KVILF GL GKRK CIGETIAR & Macaca fascicularis (crab-eating macaque) (BAA04500) \\
\hline & K VILF GL GKRK CIGETIAR & Susscrofa (pig) (NP_999577) \\
\hline & K VILF GL GKRK CIGETIAR & Felis catus (cat) (Q5KQT7) \\
\hline & K VIIF GM GKRK CIGETIAR & Homo sapiens (CAJ84704) \\
\hline & K VIF GL GKRK CIGETIAR & Bostaurus (cattle) (DAAl7555) \\
\hline & K VILF GM GKRK CIGETIAR & Cdromedarius (AFJ20719) \\
\hline & K VILF GM GKRK CIGETIAR & Neovison vison (American mink) (ACJ09355) \\
\hline & KVILF GM GKRK CIGETIAR & Enhydra lutris (sea otter) (ABQ53136) \\
\hline & KVILF GM GKRK CIGETIAR & Callithrix jacchus (white-tufted-ear marmoset) XP_002753377 \\
\hline & K VILF GM GKRK CIGETIAR & Halichoerusgrypus (grey seal) ( CAF 18539) \\
\hline & KVILF GL GKRK CIGETIGR & Rathus norvegicus (Norway rat) (AAA41025) \\
\hline & KVVLF GL G KRK CIGE TIGR & Equus caballus (ho rse) (ABW86891) \\
\hline & 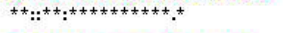 & \\
\hline \multirow{14}{*}{ CYP3A } & PYTYLPF GTGPRNCIGMR & Equus caballus (horse) (CBJ94509) \\
\hline & PYTYLPFGTGPRNCIGMR & Sus scrofa (pig) (ABS58488) \\
\hline & PYTYLPFGL G PRNCIGSR & Tribolium castaneum (red flo ur beetle) (EFA09239) \\
\hline & PYTYLPFGVGPRNCIGNR & Drosophila melanogaster (fruit fly)(AAF59290) \\
\hline & PYTYLPFGTG PRNCIGTR & C.dromedairius CYP3A (JQ619655) \\
\hline & PYTYLPFGAGPRNCIGMR & Exodesscapularis (black-legged tick) (EE C07771) \\
\hline & PYTY LPF GA GPRNCI GMR & Meleagris gallopavo (turkey) (ABE 28023) \\
\hline & PYTYLPFGAGPRNCIGMR & Gallusgallus (chicken) (CAB62060) \\
\hline & PYIYLPFGTGPRNCIGMR & Feliscatus (cat) (BAK52239) \\
\hline & PYIYLPF GNG PRNCIGMR & Rathus norvegicus (BAC23085) \\
\hline & PYMYLPFGSGPRNCIGMR & Mus musculus (CAA44754) \\
\hline & PYVYLPF GTGPRNCIGMR & Bostaurus (ABQ1 2997) \\
\hline & PYVYLPF GT GPRNCVGMR & Capra hircus (goat) (CAA54038) \\
\hline & $\star \star * * t+* * * t+* t: * *$ & \\
\hline \multirow{12}{*}{ CYP2C } & FMTF SAG KR VCVGE GLARM & C.dromedarius CYP2C (AF J20720) \\
\hline & FMTF SAG KR VCA GE GLARM & Mus musculus (EDL41818) \\
\hline & FMAF SAGKR VCVGE GLARM & Capra hircus (CAA54037) \\
\hline & FMAF SAGKRVCVGE GLARM & Equus caballus (XP_003363502) \\
\hline & FMAF SAGKRVCVGE GLARM & Bostaurus (AAP31899) \\
\hline & FKAF SA GKRVCVGE GLARM & Rathus norvegicus (EDM11921) \\
\hline & FKAF SA GKR VCVGE GLARM & Aliwropodamelanoleuca (giantpanda) (EFB28057) \\
\hline & F KAF SA GKR VCVGE GLARM & Cricetulus griseus (Chinese hamster)(E GWl3565) \\
\hline & FMPF SAGKRICVG E GLARM & Homo sapiens (AAA52145) \\
\hline & FMPF SA GKRICVGE GLARM & Macaca mulatta (ADM53743) \\
\hline & FMPF SA GKRM CVGE GLARM & Macaca fascicularis (crab-eating macaque) (ABB87194) \\
\hline & FMPF SAGKRVCL GE GLARM & Xenopuslaevis (AAH74205) \\
\hline
\end{tabular}

Figure 11. Alignment of the Camelus dromedarius CYP1A, CYP3A, and CYP2C, with the sequences of other species around the heme-binding site. Asterisks indicate conserved invariant residues; dots and semicolons denote variant residues.

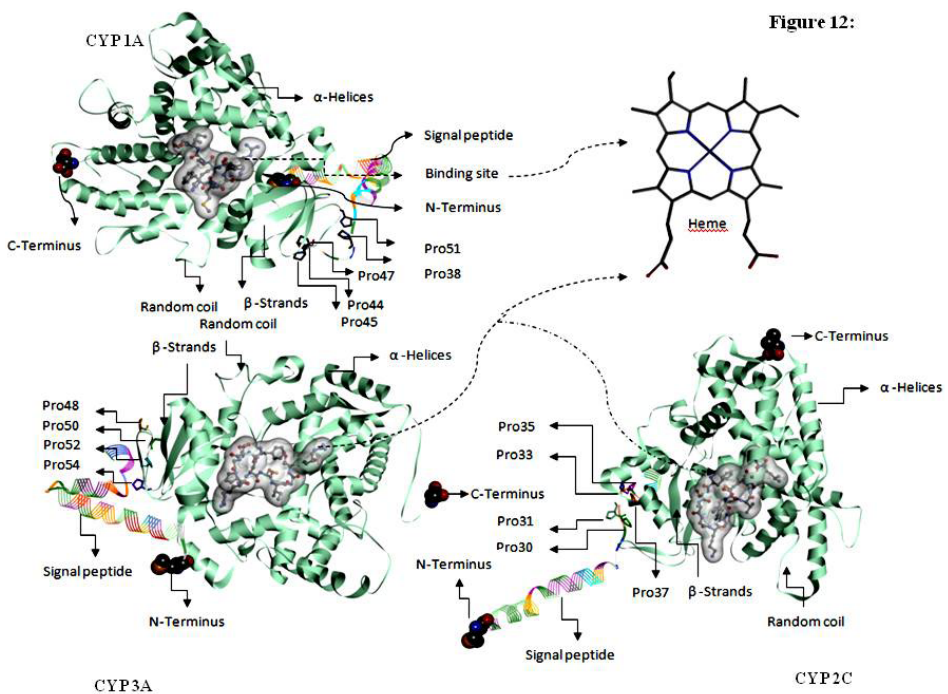

Figure 12. Predictive 3D structure models of the Camelus dromedarius CYP1A, CYP3A, and CYP2C, showing the N-terminal signal peptide, proline-rich region and the heme-binding pocket. 


\section{Cloning and expression of $C$. dromedarius CYP1A cDNA in E. coli}

The full length open reading frame of $C$. dromedarius CYP1A cDNA was cloned into the pET28a $(+)$ vector utilizing the BamHI and NotI restriction sites, and expressed in E. coli (BL21)DE3pLysS cells. A high level of recombinant fusion CYP1A was attained by adding 1.0 mM IPTG which induced the T7 promoter after an 18-h incubation period (Figure 13). The result of Western immunoblotting analysis (Figure 14) indicated that the anti-human CYP1A1 antibody cross reacted with the $C$. dromedarius recombinant CYP1A fusion protein to produce a specific cross reactivity band of about $60.0 \mathrm{kDa}$, which corresponds to the His tag fusion protein.

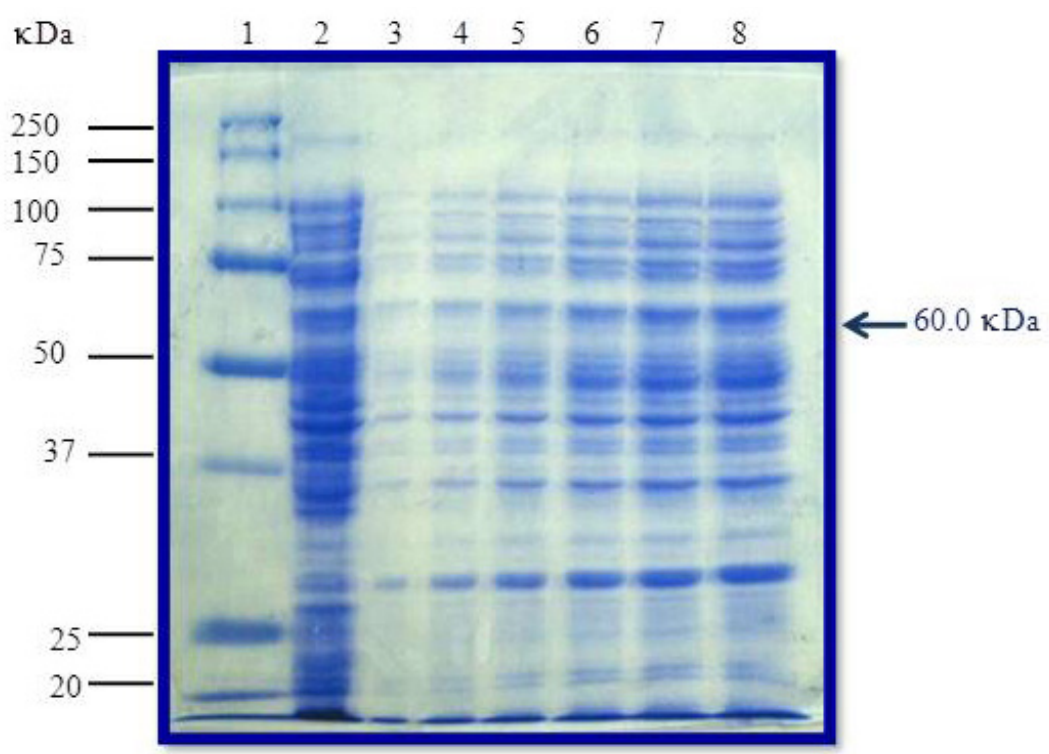

Figure 13. Sodium dodecyl sulfate gel (12\%) electrophoresis for recombinant Camelus dromedarius cytochrome P450 1A in Escherichia coli BL21(DE3)pLysS (pET28a+) induced with $1 \mathrm{mM}$ IPTG (lanes 3-8) and uninduced culture (lane 2). Lane 1 represents Precision Plus pre-stained protein standards (BioRad Cat No. 161-0373).

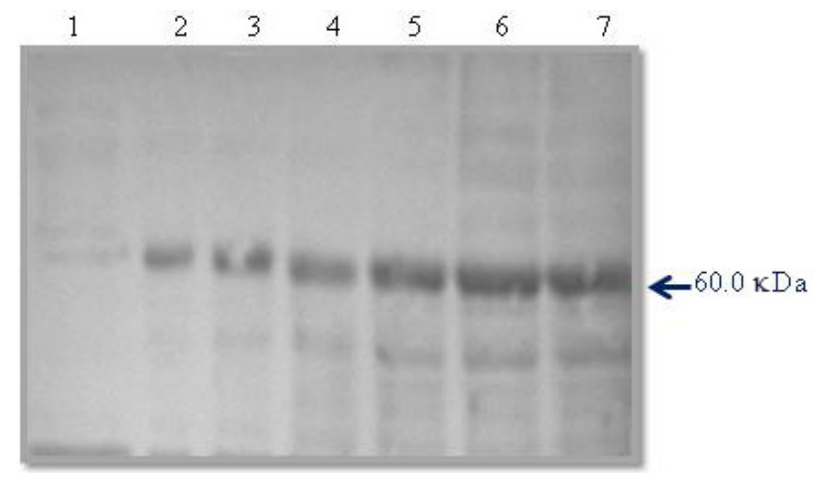

Figure 14. Immunoblotting of recombinant Camelus dromedarius CYP1A1 with anti-cytochrome P450 1A1 antibody. Lanes 2-7 = different concentrations of recombinant protein from 10 to $60 \mu \mathrm{g}$ of the induced culture proteins. Lane $1=60 \mu \mathrm{g}$ uninduced culture. 


\section{DISCUSSION}

Despite the economic, cultural, and biological importance of the Arabian camel, information remains limited about this species' Phase I drug metabolizing enzymes. The molecular characterization of Arabian camel CYP450 enzymes is very important for understanding the impact of exposure to various environmental factors on the health status of this unique animal. RT-PCR and immunoblotting results from a previous study (Alanazi et al., 2010) of $C$. dromedarius CYPs demonstrated that significant mRNA and protein of CYPs isoforms are found in camel liver and extrahepatic tissues including the lung, kidney, spleen, and testis. The present study focused on the molecular characterization of 3 important cytochrome P450s mainly, CYP1A, 3A and 2C from the Arabian camel. Cytochrome P450 1A1 is a member of a multigene family of xenobiotic metabolizing enzymes, and plays a physiological role in the detoxification of polycyclic aromatic compounds (PAHs). However, the activity of this enzyme may be deleterious, because it generates mutagenic metabolites and active oxygen (Mimura and Fujii-Kuriyama, 2003). In this gene, the induction of the CYP1A1 isoenzyme by certain environmental chemicals such as 2,3, 7, 8-tetrachlorodibenzo- $\rho$-dioxin and polymorphism primarily account for its susceptibility to $\mathrm{PAH}$-induced carcinogenesis, including lung cancer (Shah et al., 2009). CYP3A isoenzymes are the major CYPs expressed in humans, and are involved in the metabolism of majority of the drugs. Besides metabolizing drugs, these enzymes also play an important role in the metabolism of steroids and toxins, including carcinogens (Kirby et al., 1993; Gonzalez and Gelboin, 1994; Evans and Relling, 1999). Although the expression of CYP3A isoenzymes is highest in the liver, their expression has also been demonstrated in extrahepatic tissues (Michael and Doherty, 2005). Variability in the expression of CYP3A enzyme might also affect an individual's susceptibility to cancers caused by environmental procarcinogens, which are CYP3A substrates (Kirby et al., 1993). The cytochrome P450 2C subfamily is predominantly expressed in the liver, and contains 4 highly homologous genes $2 \mathrm{C} 8,2 \mathrm{C} 9,2 \mathrm{C} 18$, and $2 \mathrm{C} 19$, which are responsible for the metabolism of approximately $20 \%$ of all clinically used drugs (Michael and Doherty, 2005).

In the current study, we showed the amplification of $C$. dromedarius CYP1A, $2 \mathrm{C}$ and 3A full-length cDNA using primer sets spanning the entire open reading frame, with cDNA fragments with the anticipated sizes of 1563, 1473, and 1566 bp (Figures 1-4) being exclusively obtained. The cDNA sequences contained 520, 490, and 521 amino acid residues in the proteins of $58.651,56.03$ and $58.594 \mathrm{kDa}$, with these CYP450 enzymes being matched with several CYPs sequences in the GenBank data base (Figures 2-4). Several observations from the primary structures and from the multiple sequence alignments (Figures 2-10) of camel CYPs are of interest.

First, the primary sequence homology between camel CYPs and other species was greater than $70 \%$ (Table 1). Second, the primary structure (Figures 5-10) contained the characteristic N-terminal hydrophobic segment or signal peptide that is rich in hydrophobic amino acid residues, such as valine, leucine, isoleucine, and alanine. This signal peptide is a characteristic feature of $\mathrm{P} 450$ cytochromes which are membrane bound proteins with the exception of bacterial enzymes. Microsomal CYP enzymes are tethered to the membrane through this hydrophobic transmembrane helix at the N-terminus of the protein which also serves as a targeting sequence for the signal recognition particle dependent co-translational incorporation of a nascent CYP protein into the endoplasmic reticulum membrane (Bar-Nun et al., 1980; Sakaguchi et al., 1984). About $90 \%$ of hepatic cytochrome P450 enzymes are present in micro- 
somal membranes, with the remainder being found in the mitochondria (Nelson et al., 2004).

Third, following the N-terminal hydrophobic segment, there is a proline-rich region (Pro ${ }^{44,45,47,51}$ in CYP1A; Pro ${ }^{48,50,52,54}$ in CYP3A, and Pro ${ }^{30,31,33,35,37}$ in CYP2C) that acts as an alpha helix breaker in the folding of the CYP proteins. Fourth, there is a highly conserved hemebinding cysteine-containing peptide that is localized near the C-terminal end of the proteins (Figures 2-11). This cysteine-containing pocket is a common CYP450 signature (Guengerich, 1997), and this motif contains up to 10 amino acid residues, including the invariant cysteine residue (Cys ${ }^{465}$ in CYP1A, Cys ${ }^{451}$ in CYP3A, and $\mathrm{Cys}^{435}$ in CYP2C) which is involved in the ligation of the heme-iron prosthetic group. In general, this signature takes the form of FXXGXXXCXG (Figure 11), where $\mathrm{F}$ is phenylalanine, $\mathrm{G}$ is glycine, $\mathrm{C}$ is cysteine, and $\mathrm{X}$ is any amino acid. Fifth, a dilysine motif KKXX, (where $\mathrm{K}$ is the lysine residue and $\mathrm{X}$ is any other amino acid) at the $\mathrm{C}$ terminal end of the cytoplasmic domain was characterized in camel CYP2C $\left(\mathrm{Lys}^{420,421}\right)$ and $3 \mathrm{~A}$ $\left(\right.$ Lys $\left.^{495,496}\right)$, but it was absent in CYP1A. The dilysine motif, KKXX, facilitates the exclusion of endoplasmic reticulum microsomal CYP enzymes from being transported through the Golgi to other cell compartments, or from exocytosis (Andersson et al., 1999).

The 3D-structure of a protein provides valuable insights about its functions. Ideally, experimental tools and techniques, such as X-ray crystallography nuclear magnetic resonance (NMR) spectroscopy and electron microscopy, are used to determine the 3D-structure of proteins. Unfortunately, these techniques cannot be used on the vast majority of proteins, including microsomal cytochrome P450s, as the proteins are difficult to crystallize, insufficiently soluble, or too large for NMR studies. Alternative methods have been developed to determine the $3 \mathrm{D}$-structures of these proteins, such as comparative (or homology) modeling. It is possible to predict the 3D structure of a protein based solely on knowledge of its amino acid sequences. Hence, we generated a 3D structure of the putative $C$. dromedarius CYP1A, 3A, and $2 \mathrm{C}$, for which the nucleotide and amino acid sequences (but not the 3D structures) are known. The overall secondary structures, folding, and topology are quite similar (Figure 12). Common orientation and anchoring in the membrane by an N-terminal helix was observed for all camel CYPs under study. The heme moiety of the camel CYPs is covalently bound to the invariant Cysteine (Cys ${ }^{465}$ for CYP1A, Cys ${ }^{451}$ for CYP3A, and $\mathrm{Cys}^{435}$ for CYP2C) found in the $\beta$-bulge region called the Cys-pocket. This $\beta$-bulge appears to have the role of enveloping the invariant cysteine residue in a hydrophobic environment (Hasemann et al., 1995). Three residues besides the cysteine (Gly ${ }^{461,467}$ and $\mathrm{Phe}^{458}$ in 1A, Gly ${ }^{447,453}$ and Phe ${ }^{444}$ in $3 \mathrm{~A}$, and Gly ${ }^{431}$, ${ }^{437}$ and $\mathrm{Phe}^{428}$ in 2C) are very strictly conserved among most of the CYP450 proteins. These 2 glycine residues are involved in the formation of the $\beta$-hairpin turn and facilitate the sharp turn from the Cys-pocket into the L-helix, and are involved in determining the proximity to the heme. The phenylalanine side chain completes the hydrophobic enclosure of the proximal heme in combination with other side-chains and the main chain atoms of the Cys-pocket (Kassner, 1973; Yasukochi et al., 1994). Substrates bind to a cavity above the heme surface, because the heme forms the base of the active site cavity, and it must be positioned close to the reactive iron-oxo intermediate for catalysis (Hasemann et al., 1995). The regions that form the outer surfaces of the substrate binding cavity are generally more divergent among enzymes compared to other parts of the proteins, leading to differences in the size, shape, and chemical features of the active sites that provide discrimination for different substrates.

A pilot recombinant protein expression study using E. coli BL21(DE3) pLysS harboring pET28a $(+)$ carrying the full length CYP1A cDNA indicated that recombinant fusion camel 
CYP1A protein cross-reacted with the anti-human cytochrome P450 1A antibody (Figure 14). The cross reactivity band was found to be at a molecular weight of $60 \mathrm{kDa}$, which represents the size of the CYP1A protein in addition to a $1 \mathrm{kDa}$ His-tag fusion peptide localized at the $\mathrm{N}$-terminus of the recombinant fusion protein. Immunoreactivity was not detected in the uninduced E. coli BL21(DE3) pLysS (Figures 13, 14).

\section{CONCLUSIONS}

The molecular characterization of the Arabian camel CYP1A, 3A, and $2 \mathrm{C}$ revealed a high degree of similarity with other ungulates and human. The data presented in this study provides baseline information on which to develop further studies of camel CYP proteins, such as the characterization of the purified native and recombinant proteins and the role of camel CYPs, especially the CYP3A in the metabolism of xenobiotic compounds and environmental pollutants. Therefore, it would be useful to improve our understanding about the regulation of camel CYP1A, 3A, and 2C gene expression, in relation to the up- or downregulation of appropriate promoter elements in camel cell lines. Moreover, it is important to analyze the substrate specificity of these proteins in greater detail to obtain an appropriate level of functional characterization. Clearly, much effort is required to identify and to characterize the isolated $C$. dromedarius CYPs, and to identify more camel CYPs within the same gene family.

\section{ACKNOWLEDGMENTS}

The authors extend their appreciation to the Deanship of Scientific Research at King Saud University for funding the study through the research group project number RGP-VPP-309.

\section{Conflicts of interest}

The authors declare that there is no conflict of interest for this article and there is no financial employment, consultancies, honoraria, stock ownership or options, expert testimony, grants or patents received or pending, royalties related to this manuscript.

\section{REFERENCES}

Al-Khedhairy AA (2004). Characterization of the nucleotide sequence of a polyubiquitin gene (PUBC1) from Arabian camel, Camelus dromedarius. J. Biochem. Mol. Biol. 37: 144-147.

Alanazi MS, Saeed HM, Ataya FS and Bazzi MD (2010). Molecular characterization of the Camelus dromedarius putative cytochrome P450s genes. Protein J. 29: 306-313.

Andersson H, Kappeler F and Hauri HP (1999). Protein targeting to endoplasmic reticulum by dilysine signals involves direct retention in addition to retrieval. J. Biol. Chem. 274: 15080-15084.

Bar-Nun S, Kreibich G, Adesnik M, Alterman L, et al. (1980). Synthesis and insertion of cytochrome P-450 into endoplasmic reticulum membranes. Proc. Natl. Acad. Sci. U. S. A. 77: 965-969.

Bradford MM (1976). A rapid and sensitive method for the quantitation of microgram quantities of protein utilizing the principle of protein-dye binding. Anal. Biochem. 72: 248-254.

el Sheikh HA, Ali BH, Homeida AM and Hapke HJ (1991). Activities of glutathione-S-transferase and ethoxycoumarin$O$-deethylase in tissues of camels, sheep, goats and rats. Comp. Biochem. Physiol. C 98: 293-297.

Evans WE and Relling MV (1999). Pharmacogenomics: translating functional genomics into rational therapeutics. Science 286: 487-491.

Gonzalez FJ and Gelboin HV (1994). Role of human cytochromes P450 in the metabolic activation of chemical carcinogens 
and toxins. Drug Metab. Rev. 26: 165-183.

Guengerich FP (1997). Comparisons of catalytic selectivity of cytochrome P450 subfamily enzymes from different species. Chem. Biol. Interact. 106: 161-182.

Guengerich FP (2004). Cytochrome P450: what have we learned and what are the future issues? Drug Metab. Rev. 36: 159-197.

Hasemann CA, Kurumbail RG, Boddupalli SS, Peterson JA, et al. (1995). Structure and function of cytochromes P450: a comparative analysis of three crystal structures. Structure 3: 41-62.

Hasler JA, Estabrook R, Murray M and Pikuleva I (1999). Human cytochromes P450. Mol. Asp. Med. 20: 1-137.

Hussein MF, Al-Moen AK and Gader AMA (1992). Haemostatic parameters in the camel (Camelus dromedarius) comparison with human. Comp. Hematol. Int. 2: 92-96.

Jung ST, Lauchli R and Arnold FH (2011). Cytochrome P450: taming a wild type enzyme. Curr. Opin. Biotechnol. 22: 809-817.

Kassner RJ (1973). A theoretical model for the effects of local nonpolar heme environments on the redox potentials in cytochromes. J. Am. Chem. Soc. 95: 2674-2677.

Kirby GM, Wolf CR, Neal GE, Judah DJ, et al. (1993). In vitro metabolism of aflatoxin B1 by normal and tumorous liver tissue from Thailand. Carcinogenesis 14: 2613-2620.

Laemmli UK (1970). Cleavage of structural proteins during the assembly of the head of bacteriophage T4. Nature 227: 680-685.

Michael M and Doherty MM (2005). Tumoral drug metabolism: overview and its implications for cancer therapy. J. Clin. Oncol. 23: 205-229.

Mimura J and Fujii-Kuriyama Y (2003). Functional role of AhR in the expression of toxic effects by TCDD. Biochim. Biophys. Acta 1619: 263-268.

Nebert DW and Dalton TP (2006). The role of cytochrome P450 enzymes in endogenous signalling pathways and environmental carcinogenesis. Nat. Rev. Cancer 6: 947-960.

Nelson DR (2011). Progress in tracing the evolutionary paths of cytochrome P450. Biochim. Biophys. Acta 1814: 14-18.

Nelson DR and Strobel HW (1987). Evolution of cytochrome P-450 proteins. Mol. Biol. Evol. 4: 572-593.

Nelson DR, Kamataki T, Waxman DJ, Guengerich FP, et al. (1993). The P450 superfamily: update on new sequences, gene mapping, accession numbers, early trivial names of enzymes, and nomenclature. DNA Cell Biol. 12: 1-51.

Nelson DR, Zeldin DC, Hoffman SM, Maltais LJ, et al. (2004). Comparison of cytochrome P450 (CYP) genes from the mouse and human genomes, including nomenclature recommendations for genes, pseudogenes and alternative-splice variants. Pharmacogenetics 14: 1-18.

Ortiz AR, Strauss CE and Olmea O (2002). MAMMOTH (matching molecular models obtained from theory): an automated method for model comparison. Protein Sci. 11: 2606-2621.

Raza H, John A, Lakhani MS, Ahmed I, et al. (1998). Multiplicity and tissue specific expression of camel cytochrome P450(s). Comp. Biochem. Physiol. C Pharmacol. Toxicol. Endocrinol. 121: 205-211.

Raza H, Bhagwat SV and John A (2004). Flavin-containing monooxygenase activity in camel tissues: comparison with rat and human liver enzymes. Comp. Biochem. Physiol. C Toxicol. Pharmacol. 139: 289-293.

Rooney PH, Telfer C, McFadyen MC, Melvin WT, et al. (2004). The role of cytochrome P450 in cytotoxic bioactivation: future therapeutic directions. Curr. Cancer Drug Targets. 4: 257-265.

Roy A, Kucukural A and Zhang Y (2010). I-TASSER: a unified platform for automated protein structure and function prediction. Nature Protocols 5: 725-738.

Sakaguchi M, Mihara K and Sato R (1984). Signal recognition particle is required for co-translational insertion of cytochrome P-450 into microsomal membranes. Proc. Natl. Acad. Sci. U. S. A. 81: 3361-3364.

Sambrook J, Frisch E and Maniatis T (1989). Molecular Cloning: A Laboratory Manual. 2nd edn. Cold Spring Harbor Laboratory Press, New York.

Sanger F, Nicklen S and Coulson AR (1977). DNA sequencing with chain-terminating inhibitors. Proc. Natl. Acad. Sci. U. S. A. 74: 5463-5467.

Seliskar M and Rozman D (2007). Mammalian cytochromes P450--importance of tissue specificity. Biochim. Biophys. Acta 1770: 458-466.

Shah PP, Saurabh K, Pant MC, Mathur N, et al. (2009). Evidence for increased cytochrome P450 1A1 expression in blood lymphocytes of lung cancer patients. Mutat. Res. 670: 74-78.

Stiborova M, Rupertova M and Frei E (2011). Cytochrome P450- and peroxidase-mediated oxidation of anticancer alkaloid ellipticine dictates its anti-tumor efficiency. Biochim. Biophys. Acta 1814: 175-185.

Thomas D, Bunch Warren C and Foote AM (1985). Chromosome banding pattern homologies and NORs for the Bacterian camel, guanaco and IIama. J. Hered. 76: 115-118.

Towbin H, Staehelin T and Gordon J (1979). Electrophoretic transfer of proteins from polyacrylamide gels to nitrocellulose 
sheets: procedure and some applications. Proc. Natl. Acad. Sci. U. S. A. 76: 4350-4354.

Uppstad H, Ovrebo S, Haugen A and Mollerup S (2010). Importance of CYP1A1 and CYP1B1 in bioactivation of benzo[a] pyrene in human lung cell lines. Toxicol. Lett. 192: 221-228.

Yasukochi T, Okada O, Hara T, Sagara Y, et al. (1994). Putative functions of phenylalanine-350 of Pseudomonas putida cytochrome P-450cam. Biochim. Biophys. Acta 1204: 84-90. 